\title{
Charakter prawny wyroków wydawanych przez Krajową Izbę Odwoławczą
}

\section{Wprowadzenie}

Przepisy ustawy Prawo zamówień publicznych ${ }^{1}$ normują wiele kwestii związanych nie tylko z procesem udzielania zamówień publicznych, ale również z kontrolą sprawowaną przez prezesa Urzędu Zamówień Publicznych (UZP) oraz Krajową Izbę Odwoławczą (KIO, Izba) nad podmiotami pierwszoplanowymi. Sfera publicznoprawnego oddziaływania na stosunki prawne zachodzące pomiędzy zamawiającymi a wykonawcami, pomimo drugoplanowego charakteru, ma niewątpliwie istotne znaczenie dla prawidłowego funkcjonowania systemu zamówień publicznych. Skuteczne realizowanie funkcji, jaką pełnić mają podmioty oddziałujące na zachowania zamawiających oraz wykonawców, wymaga między innymi posiadania przez nie klarownego statusu prawnego oraz dysponowania skutecznymi instrumentami prawnymi.

Na wstępie należy zauważyć, że ani status ustrojowy $\mathrm{KIO}^{2}$, ani charakter prawny postępowania odwoławczego toczącego się przed tym

${ }^{1}$ Ustawa z dnia 29 I 2004 r. Prawo zamówień publicznych (tekst jedn. Dz.U. 2015, poz. 2164 ze zm.), dalej "p.z.p.”.

${ }^{2}$ Zob. K. Solecka, Pozycja prawnoustrojowa Krajowej Izby Odwoławczej, w: Kontrola zamówień publicznych. Materiały pokonferencyjne VI Konferencji naukowej UZP, pod red. T. Kocowskiego, J. Sadowego, Wrocław-Warszawa 2013, s. 199-205; J. Niczyporuk, Krajowa Izba Odwoławcza - organ administracji regulacyjnej, w: Nowe podejście do zamówień publicznych - zamówienia publiczne jako instrument zwiększania innowacyjności gospodarki i zrównoważonego rozwoju. Doświadczenia polskie i zagraniczne. Materiały pokonferencyjne IV Konferencji naukowej UZP, Kazimierz Dolny 2011, s. 105-110; A. Panasiuk, Pozycja ustrojowa Krajowej Izby Odwoławczej, w: System zamówień publicznych. Zarys wykładu, Warszawa 2013, s. 199-205. 
organem ${ }^{3}$, ani również charakter prawny orzeczeń wydawanych przez ten organ, nie są w doktrynie postrzegane w sposób jednomyślny. Powyższe wynika bezpośrednio z niejednoznacznego uregulowania wspomnianej materii przez ustawodawcę, a także niewypracowania zgodnego stanowiska w kwestii klasyfikacji prawa zamówień publicznych do jednej z tradycyjnie wyróżnianych gałęzi prawa: administracyjnego albo cywilnego ${ }^{4}$.

Rozważania poczynione w ramach niniejszego artykułu zawężone są do charakteru prawnego wyroków wydawanych przez KIO, a więc orzeczeń rozstrzygających sprawę co do istoty (art. 192 p.z.p.). Dotychczas najszerszą refleksję w tym zakresie poczyniła J. May ${ }^{5}$, przyjmując w swoich rozważaniach optykę, którą można określić mianem umiarkowanie cywilistycznej. Pomimo uznania KIO za "pozasądowy organ rozstrzygający, który w zakresie powierzonych mu zadań z zakresu zamówień publicznych pełni funkcje orzecznicze" ${ }^{\prime \prime}$, dalsza część rozważań, w tym typologia orzeczeń, została poczyniona przy wykorzystaniu „bogatego dorobku nauki postępowania cywilnego"7. W ramach konkluzji wskazano, „że jurydyczna konstrukcja orzeczeń KIO wpisuje się w koncepcję rozstrzygnięć pierwszoinstancyjnych w sprawach cywilnych"8.

Wyraźnie zastrzegając, że intencją autora nie jest próba bagatelizowania znaczenia argumentów cywilistycznych, popierając opinię wyrażoną przez J. Niczyporuka o szkodliwości lansowania przez cywilistyczne środowiska opiniotwórcze wyłącznie im bliskiej koncepcji zamówień publicznych ${ }^{9}, \mathrm{w}$ ramach niniejszego artykułu podjęta zostanie próba administracyjnoprawnej analizy charakteru orzeczeń wydawanych przez KIO.

${ }^{3}$ Zob. M. Grabarczyk, M. Stręciwilk, Charakter postępowania spornego przed Krajową Izba Odwoławcza, „Prawo Zamówień Publicznych” 2013, nr 4, s. 95; J. Niczyporuk, Skuteczność postępowania odwoławczego w zamówieniach publicznych, w: Zamówienia publiczne jako instrument sprawnego wykorzystania środków unijnych, pod red. E. Adamowicz, J. Sadowego, Gdańsk-Warszawa 2012, s. 38-40.

${ }^{4}$ Zob. K. Horubski, Publiczno- i prywatnoprawne elementy zamówień publicznych, „Państwo i Prawo" 2009, z. 7, s. 83-84.

${ }^{5}$ J. May, Charakter prawny orzeczeń Krajowej Izby Odwoławczej w sporach przedumownych z zakresu zamówień publicznych, „Prawo Zamówień Publicznych” 2015, nr 3, s. 119-135.

${ }^{6}$ Ibidem, s. 125.

${ }^{7}$ Ibidem, s. 129.

${ }^{8}$ Ibidem, s. 134.

${ }_{9}^{9}$ J. Niczyporuk, Skuteczność postępowania odwoławczego..., s. 35. Przywołana opinia powinna być postrzegana jako postulat mobilizacji środowiska administracyjnego w podejmowaniu działań na rzecz tworzenia podbudowy teoretycznej prawa zamówień publicznych. 


\section{Cel postępowania odwoławczego}

Przed przystąpieniem do rozważań szczegółowych niezbędne jest przedstawienie elementów stałych i pewnych, które potraktowane zostaną jako punkt wyjścia. Są nimi: charakter organizacyjno-ustrojowy KIO oraz postępowania odwoławczego. Pogłębiona analiza tychże kwestii została poczyniona w artykule Charakterystyka środków ochrony prawnej przewidzianych przepisami ustawy Prawo zamówień publicznych ${ }^{10}$. W tym miejscu należy jedynie wskazać, że KIO jest samodzielnym kolegialnym organem administracji publicznej, pełniącym określone prawem funkcje jurysdykcyjne w zakresie wyspecjalizowanej dziedziny prawa, jaką stanowią zamówienia publiczne. Zważając na treść art. 10 w zw. z art. 175 Konstytucji Rzeczypospolitej Polskiej ${ }^{11}$, przynależność tego organu do egzekutywy, a nie do judykatywy, nie powinna budzić wątpliwości. Podobnie jak w przypadku Samorządowych Kolegiów Odwoławczych (SKO) i Regionalnych Izb Obrachunkowych (RIO), nie zmienia tego pełnienie przez nie funkcji orzeczniczej.

Celem utworzenia KIO jest zapewnienie legalności działań zamawiających w ramach poszczególnych postępowań o udzielenie zamówienia, co sprzyjać ma zarówno interesowi publicznemu, jak i interesowi prywatnemu poprzez zapewnienie stanu sprawiedliwości proceduralnej. Realizacji tego celu służyć ma kontrola zachowań instytucji zamawiających dokonywana przez ten organ $\mathrm{w}$ ramach postępowania odwoławczego. Należy zauważyć, że w świetle rozwiązań przyjętych w p.z.p. może ona zostać zainicjowana wyłącznie na wniosek podmiotów uprawnionych. Legitymacja do wniesienia wniosku, w ramach p.z.p. konwencjonalnie nazwanego odwołaniem, przysługuje: wykonawcy, uczestnikowi konkursu, a także innemu podmiotowi, jeżeli ma lub miał interes w uzyskaniu danego zamówienia oraz poniósł lub może ponieść szkodę w wyniku naruszenia przez zamawiającego przepisów p.z.p. (art. 179 ust. 1 p.z.p.). Ponadto możliwość skorzystania ze środków ochrony prawnej przysługuje również organizacjom wpisanym na listę na podstawie wydanej decyzji administracyjnej przez prezesa UZP (art. 179 ust. 2 p.z.p.). Wykorzystanie w postępowaniu odwoławczym

${ }^{10}$ K. Różowicz, Charakterystyka środków ochrony prawnej przewidzianych przepisami ustawy Prawo zamówień publicznych, "Studia Prawa Publicznego" 2014, nr 4(8), s. $129-155$.

${ }^{11}$ Konstytucja Rzeczypospolitej Polskiej z dnia 2 IV 1997 r. (Dz.U. Nr 78, poz. 483 ze zm.), dalej „Konstytucja RP”. 
mechanizmu inicjowania kontroli przez podmioty z założenia najbardziej zainteresowane prawidłowością przebiegu postępowania umożliwia ochronę interesu publicznego i prywatnego przed niezgodnymi z prawem działaniami gospodarzy postępowań.

Zasadnicze znaczenie dla kształtu tej procedury weryfikacyjnej maja przepisy Rozdziału 2 Działu VI p.z.p. Ponadto postępowanie odwoławcze normują dwa rozporządzenia prezesa Rady Ministrów: w sprawie regulaminu postępowania przy rozpoznawaniu odwołann ${ }^{12}$ oraz w sprawie wysokości i sposobu pobierania wpisu od odwołania ${ }^{13}$. W zakresie nieuregulowanym w p.z.p., zgodnie $z$ art. 185 ust. 7 p.z.p. do postępowania odwoławczego stosuje się przepisy kodeksu postępowania cywilnego ${ }^{14}$ o sądzie polubownym, jeżeli ustawa nie stanowi inaczej. Zakres przedmiotowy kontroli określa art. 180 ust. 1 p.z.p. w zw. z art. 2 pkt 7a p.z.p., zgodnie z którym odwołanie przysługuje wyłącznie od niezgodnej z przepisami ustawy czynności zamawiającego podjętej w postępowaniu o udzielenie zamówienia, poprzez które należy rozumieć postępowanie w celu dokonania wyboru oferty wykonawcy, z którym zostanie zawarta umowa w sprawie zamówienia publicznego. Podejmowana przez KIO kontrola dotyczyć może wyłącznie działań i zaniechań zamawiającego podejmowanych w celu wyboru oferty najkorzystniejszej, a postępowanie odwoławcze nakierowane jest na korygowanie nieprawidłowości występujących na tym etapie. Zważając na całokształt kwestii związanych z postępowaniem odwoławczym, należy uznać, że celem kontroli przeprowadzanej w wyniku skorzystania ze środków ochrony prawnej nie jest wyciągnięcie konsekwencji względem zamawiającego naruszającego prawo, lecz skorygowanie jego działań i czynności tak, aby udzielono zamówienia publicznego podmiotowi wybranemu w sposób zgodny z przepisami p.z.p. O korygującym charakterze postępowania świadczy między innymi art. 181 ust. 1 p.z.p. Tezę tę umacnia również rozwiązanie normatywne pozwalające zamawiającemu na podjęcie samokontroli zarówno przed wydaniem

12 Rozporządzenie Prezesa Rady Ministrów z dnia 22 III 2010 r. w sprawie regulaminu postępowania przy rozpoznawaniu odwołań (tekst jedn. Dz.U. 2014, poz. 964).

${ }^{13}$ Rozporządzenie Prezesa Rady Ministrów z dnia 15 III 2010 r. w sprawie wysokości i sposobu pobierania wpisu od odwołania oraz rodzajów kosztów w postępowaniu odwoławczym i sposobu ich rozliczania (Dz.U. Nr 41, poz. 238).

${ }^{14}$ Ustawa z dnia 17 XI 1964 r. Kodeks postępowania cywilnego (tekst jedn. Dz.U. 2014, poz. 101 ze zm.), dalej „k.p.c.”. 
orzeczenia przez $\mathrm{KIO}^{15}$, jak i po nim, która to samokontrola eliminuje konieczność korygowania jego działań przez ten organ ${ }^{16}$. O korygującym charakterze postępowania odwoławczego świadczą także rodzaje rozstrzygnięć, jakie może orzec KIO. Po merytorycznym rozstrzygnięciu sprawy, a więc wtedy, gdy przedmiotem rozpoznania była jej istota, wydawany jest wyrok oddalający lub uwzględniający. Regulacje p.z.p. expressis verbis dookreślaja, kiedy zostanie wydane orzeczenie o danej treści. KIO uwzględnia odwołanie, jeżeli stwierdzi naruszenie przepisów ustawy, które miało wpływ lub może mieć istotny wpływ na wynik postępowania o udzielenie zamówienia ${ }^{17}$. Treść wyroku uwzględniającego odwołanie jest uzależniona od tego, czy umowa została czy też nie została zawarta, czy zobowiązanie zostało wykonane, a także czy utrzymanie umowy w mocy leży w ważnym interesie publicznym. Stosownie do art. 192 ust. 3 p.z.p., uwzględniając odwołanie, jeżeli umowa w sprawie zamówienia publicznego nie została zawarta, KIO może nakazać wykonanie lub powtórzenie czynności zamawiającego lub nakazać unieważnienie czynności zamawiającego. Jeżeli umowa została zawarta oraz zachodzi jedna z przesłanek wskazanych w art. 146 ust. 1 p.z.p., KIO może:

1. unieważnić umowę albo

2. unieważnić umowę w zakresie zobowiązań niewykonanych i nałożyć karę finansową w uzasadnionych przypadkach, w szczególności gdy nie jest możliwy zwrot świadczeń spełnionych na podstawie umowy podlegającej unieważnieniu, albo

3. nałożyć karę finansową lub orzec o skróceniu okresu obowiązywania umowy w przypadku stwierdzenia, że utrzymanie umowy w mocy leży w ważnym interesie publicznym, w szczególności w dziedzinach obronności i bezpieczeństwa, albo

4. stwierdzić naruszenie przepisów ustawy, jeżeli została ona zawarta w okolicznościach dopuszczonych w ustawie ${ }^{18}$.

\footnotetext{
${ }^{15}$ K. Różowicz, Uprawnienia zamawiającego do samokontroli, „Monitor Zamówień Publicznych" 2015, nr 8(132), s. 23-25.

${ }^{16}$ Wyrok KIO z 19 XI 2012 r., sygn. KIO 2441/12, LEX nr 1237673; wyrok KIO z 18 III 2011 r., sygn. KIO 459/11, LEX nr 788088.

${ }^{17}$ K. Różowicz, Analiza sformułowania "wpływ na wynik postępowania" w prawie zamówień publicznych, cz. III, LEX nr 271269.

18 Zob. K. Różowicz, Umowa na cenzurowanym, "Monitor Zamówień Publicznych” 2016, nr 1(137), s. 40-43.
} 


\section{Charakter postępowania odwoławczego}

Przytoczone cechy postępowania odwoławczego stanowią podstawę oceny jego charakteru. Za punkt wyjścia dalszej analizy przyjęta została konstatacja, oparta na koncepcji podmiotowej, że zasadniczo postępowanie toczące się przed organem administracyjnym ma charakter postępowania administracyjnego.

Za dominujący w doktrynie prawa zamówień publicznych należy uznać pogląd przeciwny, zgodnie z którym postępowanie odwoławcze jest postępowaniem cywilnym ${ }^{19}$. Argumenty przemawiające za tą tezą odwołują się do charakteru postępowania o udzielenie zamówienia, jurysdykcyjnego charakteru postępowania odwoławczego oraz uzupełniającego stosowania w procedurze odwoławczej przepisów k.p.c. o sądzie polubownym. Odnosząc się do argumentu z charakteru postępowania o udzielenie zamówienia publicznego, nie podejmując w tym miejscu próby analizy, czy ma ono charakter cywilny czy administracyjny ${ }^{20}$, należy wskazać, że pomimo iż pomiędzy tymi postępowaniami istnieje niewątpliwy związek, nie sposób podzielić poglądu, zgodnie z którym charakter jednego postępowania musi implikować charakter innego. Widoczne jest to w przypadku tzw. postępowań hybrydowych ${ }^{21}$. Oparcie się na argumencie ciągłości charakteru prawnego dwóch odrębnych postępowań, przy jednoczesnym uwzględnieniu odrębnego celu tych dwóch procedur, zdaje się rozwiązaniem nie w pełni zasadnym.

Zważając na istnienie w krajowym systemie prawnym postępowań o charakterze hybrydowym ${ }^{22}$, nie jest również zasadne określanie charakteru prawnego postępowania odwoławczego poprzez odwołanie się do cech postępowania skargowego, w którym sądy powszechne rozpoznają środki zaskarżenia na orzeczenia $\mathrm{KIO}^{23}$.

${ }^{19}$ Zob. M. Grabarczyk, M. Stręciwilk, op. cit., s. 93-115; R. Szostaj, Zmiany w zakresie środków ochrony prawnej wykonawców ubiegajacych się o zamówienia publiczne, „Prawo Zamówień Publicznych" 2010, nr 1, s. 4-34.

${ }^{20}$ Ocena charakteru postępowania o udzielenie zamówienia publicznego stanowi kwestię złożoną i niejednoznaczną, co może przenosić dyskusję o charakter postępowania odwoławczego na inny poziom bez rozwiązania problemu.

${ }^{21}$ Z. Kmieciak, Postepowanie w sprawach ochrony konkurencji a koncepcja procedury hybrydowej, "Państwo i Prawo” 2002, z. 4, s. 46-47.

22 Odrębną kwestią pozostaje ocena istnienia w porządku prawnym takiego rodzaju postępowań oraz ich wpływu na spójność systemu.

${ }^{23}$ Należy przy tym zauważyć, że nieodzowność poddania orzeczeń wydawanych przez organy nieprzynależące do judykatywy kontroli sądowej wynika z minimalnego 
Rozszerzając zakres przywołanego argumentu, również charakter sprawy nie zawsze determinuje charakter postępowania. Lege iuris kryterium to nie jest na gruncie polskich rozwiązań normatywnych precyzyjne. $W$ krajowym porządku prawnym istnieją sprawy o charakterze cywilnym, które podlegają ocenie dokonywanej przez organy administracji publicznej. Przykładowo, zgodnie z art. 39 ust. 3 ustawy Prawo geodezyjne i kartograficzne ${ }^{24}$ spory o zakres prawa własności do nieruchomości, a precyzując, o ich rozgraniczenie, rozpoznają wójtowie (burmistrzowie, prezydenci miast). Sprawy o rozgraniczenie nieruchomości dotyczące stosunków własnościowych mają charakter cywilnoprawny ${ }^{25}$, a postępowanie przed wójtem (burmistrzem, prezydentem miasta) ma charakter administracyjny. Wskazać można również na sytuację odwrotną. Zgodnie z unormowaniami art. $20 \S 4$, art. 22 § 5, art. $111 \S 1$ czy art. 392 § 1 Kodeksu wyborczego ${ }^{26}$, regulującego materię stricte administracyjna, kompetencje kontrolne i orzecznicze przysługuja sądom powszechnym, zasadniczo rozpoznającym sprawy o charakterze cywilnym. Powyższe egzemplifikacje ukazują, że nie istnieje możliwość prostego określenia charakteru prawnego postępowania poprzez odwołanie się do charakteru sprawy rozpoznawanej.

Kolejna grupa argumentów odnosi się do sposobu ukształtowania postępowania odwoławczego i odwzorowania go na postępowaniu sądowym. W istocie wykazują one, że wynikająca ze sporności kontradyktoryjność postępowania, a więc zobowiązanie stron postępowania do zebrania i przedstawienia materiału dowodowego ${ }^{27}$, nie przystaje do cech postępowań administracyjnych ${ }^{28}$. Należy zauważyć, że kontradyktoryjność postępowania stanowi emanację działania KIO wyłącznie na wniosek strony oraz sporności stanowisk stron w postępowaniu, które podlegają ocenie przez ten organ. Ze względu na pełnienie przez KIO funkcji jurysdykcyjnej właściwsze zdaje się odwołanie do charakteru postępowań sądowych. Zarówno w postępowaniu procesowym przed

standardu konstytucyjnego (art. 184 Konstytucji RP). Zob. wyrok Trybunału Konstytucyjnego z 8 XII 1998 r., sygn. K 41/97, OTK ZU 1998, nr 7, poz. 117.

${ }^{24}$ Ustawa z dnia 17 V 1989 r. Prawo geodezyjne i kartograficzne (tekst jedn. Dz.U. 2015, poz. 520).

${ }^{25}$ Zob. E. Stefańska, Komentarz do art. 29 ustawy - Prawo geodezyjne i kartograficzne, LEX nr 143747.

${ }^{26}$ Ustawa z dnia 5 I 2011 r. Kodeks wyborczy (Dz.U. Nr 21, poz. 112 ze zm.).

27 J. Glos, Ciężar dowodu w postępowaniu administracyjnym, "Prawo i Podatki” 2006, z. 12, s. 28.

${ }^{28}$ W. Dawidowicz, Zarys procesu administracyjnego, Warszawa 1989, s. 10. 
sądami cywilnymi, jak i administracyjnymi ${ }^{29}$ obowiązuje zasada kontradyktoryjności i cecha ta nie przesądza o charakterze postępowania.

Prowadząc rozważania dotyczące charakteru prawnego postępowania odwoławczego, nie sposób pominąć okoliczności, że również inne organy administracji publicznej pełniące taką funkcję, np. przywołane SKO oraz RIO, nie działają na podstawie zasady kontradyktoryjności, co może świadczyć o cywilnoprawnym charakterze postępowania przed KIO. Trudność dokonania jednoznacznej oceny opartej na kryterium kontradyktoryjności wynika ze swobodnej możliwości uregulowania tej kwestii przez ustawodawcę między innymi w ramach szczególnej procedury kontrolnej stosowanej przez KIO. Zachowanie czystości rozwiązań w ramach poszczególnych działów prawa nie stanowi domeny krajowej legislatywy, zasadniczo kierującej się względami pragmatycznymi. Do kategorii argumentów przemawiających za odstąpieniem od zasady inkwizycyjności niewątpliwie można zaliczyć paradygmat szybkości postępowania odwoławczego (art. 189 ust. 1 p.z.p.), znacznie przyśpieszający postępowanie w porównaniu z postępowaniami prowadzonymi na podstawie przepisów Kodeksu postępowania administracyjnego ${ }^{30}$ (art. 35 k.p.a. w zw. z art. 12 k.p.a.).

Kolejnym argumentem przemawiającym, zdaniem części doktryny, za cywilistycznym charakterem postępowania odwoławczego jest odesłanie do przepisów k.p.c. o sądzie polubownym, jeżeli ustawa nie stanowi inaczej. W literaturze zauważa się jednak, że odwołanie do regulacji części piątej k.p.c. nie oznacza automatycznie, iż określone przepisy należą do tej części systemu prawnego, do której jest to odesłanie $^{31}$, a samo postępowanie ma charakter cywilny. Zważając na pozycję prawnoustrojową KIO, a także założenie racjonalności prawodawcy, należy uznać, że odwołanie to jest zasadne, gdyż ustanawia wyjątek stosowania przepisów k.p.c. w toku postępowania administracyjnego. Podobne rozwiązanie zostało przyjęte $w$ art. 84 ustawy o ochronie konkurencji i konsumentów ${ }^{32}$ wskazującym, że w sprawach dotyczących dowodów w postępowaniu przed prezesem Urzędu Ochrony Konku-

${ }^{29}$ Por. Z. Kmieciak, Odwołania w postępowaniu administracyjnym, Warszawa 2011, s. 176.

${ }^{30}$ Ustawa z dnia 13 VI 1960 r. Kodeks postępowania administracyjnego (tekst jedn.

Dz.U. 2016, poz. 23), dalej „k.p.a.”.

${ }^{31} \mathrm{~J}$. Niczyporuk, Krajowa Izba Odwoławcza..., s. 105-110.

${ }^{32}$ Ustawa z dnia 16 II 2007 r. o ochronie konkurencji i konsumentów (tekst jedn.

Dz.U. 2015, poz. 184). 
rencji i Konsumentów, w zakresie nieuregulowanym w ustawie, stosuje się odpowiednio art. 227-315 k.p.c.

Na marginesie czynionych rozważań w związku z tematem przewodnim artykułu należy zauważyć, że przywołane odwołanie ma znikomą doniosłość praktyczną, albowiem regulacje kodeksowe o sądzie arbitrażowym są niewystarczające dla zapewnienia odpowiedniej kontroli działań zamawiających oraz ochrony interesu podmiotów uprawnionych do inicjowania postępowania weryfikacyjnego.

Czyniąc rozważania odnoszące się do charakteru postępowania przed KIO, należy zauważyć, że p.z.p. jest jedną z trzech regulacji tworzących system prawa zamówień w Polsce. Zważając na postulat spójności systemu prawnego należy wskazać na charakter postępowań odwoławczych uregulowanych $w$ ustawie o koncesji na roboty budowlane lub usługi ${ }^{33}$ oraz ustawie o partnerstwie publiczno-prywatnym ${ }^{34}$. Zgodnie $z$ art. 27 u.k.b. zainteresowane podmioty, których interes doznał uszczerbku z powodu naruszenia regulacji tejże ustawy, moga wnieść skargę do sądu administracyjnego, a postępowanie odbywa się zgodnie z przepisami ustawy Prawo o postępowaniu przed sądami administracyjnymi ${ }^{35}$. W literaturze podkreśla się, że "sprawę koncesji wobec szerokiej definicji sprawy sądowoadministracyjnej w rozumieniu art. 1 ustawy z 30 sierpnia 2002 r. Prawo o postępowaniu przed sądami administracyjnymi można zasadnie uznać za sprawę administracyjną" ${ }^{\prime \prime}$.

Zgodnie $z$ art. 4 ust. 1 p.p.p., jeżeli wynagrodzeniem partnera prywatnego jest prawo do pobierania pożytków z przedmiotu partnerstwa publiczno-prywatnego albo przede wszystkim to prawo wraz z zapłata sumy pieniężnej, do wyboru partnera prywatnego i umowy o partnerstwie publiczno-prywatnym, w zakresie nieuregulowanym przepisami p.p.p., stosuje się przepisy u.k.b. Natomiast w innych przypadkach do wyboru partnera prywatnego i umowy o partnerstwie publiczno-prywatnym stosuje się przepisy p.z.p.

Odwołując się do racjonalności prawodawcy oraz przyjmując, że sprawa administracyjna, jaką jest uzyskanie koncesji w trybie u.k.b,

${ }^{33}$ Ustawa z dnia 9 I 2009 r. o koncesji na roboty budowlane lub usługi (tekst jedn. Dz.U. 2015, poz. 113), dalej „u.k.b.”.

${ }^{34}$ Ustawa z dnia 19 XII 2008 r. o partnerstwie publiczno-prywatnym (tekst jedn. Dz.U. 2015, poz. 696), dalej „p.p.p.”.

${ }^{35}$ Ustawa z dnia 30 VIII 2002 r. Prawo o postępowaniu przed sądami administracyjnymi (tekst jedn. Dz.U. 2012, poz. 270 ze zm.), dalej "p.p.s.a.”.

${ }^{36}$ A. Mikołajczak-Waligórska, M.A. Waligórski, Sądowa kontrola umów koncesyjnych motywowana interesem publicznym, w: Kontrola zamówień publicznych..., s. 105. 
nie przestaje nią być ze względu na odmienny sposób wynagradzania wykonawcy (koncesjonariusza), zasadne jest przyjęcie, że zarówno postępowanie przed $\mathrm{KIO}$, jak i przed sądami administracyjnymi ma charakter administracyjny (ze względu na ustrojową pozycję sądów administracyjnych, w przypadku regulacji u.k.b. - sądowoadministracyjny).

Biorąc pod uwagę przedstawione argumenty, postępowanie odwoławcze przed KIO należy uznać za postępowanie administracyjne odrębne ${ }^{37}$. Postępowanie to stanowi specjalną procedurę dostosowaną do specyfiki działań zamawiających zmierzających do udzielenia zamówienia oraz realizacji swoich potrzeb, związanych bezpośrednio albo pośrednio z potrzebami publicznymi.

\section{Umiejscowienie orzeczeń KIO wśród indywidualnych aktów stosowania prawa}

Orzeczenia wydawane przez KIO należy zaliczyć do kategorii indywidualnych aktów stosowania prawa, w których organ, działając na podstawie i w granicach prawa, objawia swoją wolę regulacji sytuacji prawnej zamawiającego, a pośrednio również wykonawców. Do kategorii indywidualnych aktów stosowania prawa zaliczyć można zarówno indywidualne akty administracji publicznej, orzeczenia sądów państwowych, jak i orzeczenia sądów polubownych. Niezbędne jest zatem podjęcie próby zaklasyfikowania orzeczeń KIO do jednej z wyżej wymienionych kategorii.

\subsection{Wyroki KIO a wyroki sądów powszechnych}

Zgodnie z regulacjami p.z.p. KIO rozstrzyga sprawy w formie wyroków oraz postanowień (art. 192 ust. 1 p.z.p.). Ze względu na nazewnictwo, którym posłużył się ustawodawca, nieodzowne są skojarzenia z prawnymi formami działania judykatywy. W świetle rozważań przedstawicieli prawa procesowego (zarówno cywilnego, jak i administracyjnego) wyrok jest podstawową czynnością decyzyjną sądu o charakterze

${ }^{37}$ S. Fundowicz określa je mianem wyjątkowego, zob. idem, Miejsce prawa o zamówieniach publicznych w prawie administracyjnym, w: XV-lecie systemu zamówień publicznych w Polsce, pod red. H. Nowickiego, J. Sadowego, Toruń-Warszawa 2009, s. 45. 
merytorycznym, rozstrzygająca sprawę co do istoty ${ }^{38}$. W tym akcie decyzyjnym organ, zgodnie z obowiązującymi przepisami, orzeka co do istoty przedstawionego mu zagadnienia ${ }^{39}$. „W rozstrzygnięciu o charakterze merytorycznym sąd administracyjny orzeka o przedmiocie tego postępowania. W ten sposób wykonuje w stosunku do konkretnej sprawy [...] funkcję jako organu sprawującego wymiar sprawiedliwości" ${ }^{\prime 4}$.

Cechą wspólną wszystkich wyroków wydawanych przez organy sądownicze jest ich solenny charakter. Zgodnie z art. 174 Konstytucji RP tylko Sądy i Trybunały wydają wyroki w imieniu Rzeczypospolitej Polskiej. Powyższy przepis odróżnia wyroki sądowe od rozstrzygnięć innych podmiotów, w tym organów administracji publicznej. Należy zauważyć, że pozycja ustrojowa KIO implikuje brak solennego charakteru wyroków wydawanych przez ten organ.

Akty wydawane przez KIO stanowią zatem odrębną od orzeczeń organów sądowniczych kategorię prawną. Nie modyfikuje tego regulacja art. 197 ust. 1 p.z.p., zgodnie z którą orzeczenie KIO, po stwierdzeniu przez sąd wykonalności, ma moc prawną równą z wyrokiem sądu. Przywołany przepis nie zmienia bowiem istoty orzeczeń $\mathrm{KIO}$, ale jedynie zrównuje je z wyrokami sądów w ograniczonym zakresie, niezbędnym dla ich wykonania w drodze egzekucji (art. 197 ust. 3 p.z.p.).

Powyższe potwierdza również art. 781 § 2 k.p.c., do którego odsyła art. 197 ust. 1 p.z.p., regulujący właściwość sądu nadającego klauzulę wykonalności tytułom egzekucyjnym pochodzącym od sądów administracyjnych oraz "innym tytułom”. Akt wydany przez KIO należy zaklasyfikować do zakresu innych tytułów egzekucyjnych. Odnosząc się do treści przytoczonego art. 197 p.z.p., stosując argumentację a contrario, orzeczenia, w stosunku do których nie stwierdzono wykonalności, nie mają mocy prawnej równej orzeczeniom sądowym. Nie uzyskają jej orzeczenia KIO nienadające się do wykonania, a więc takie, które nie zawierają szczegółowo określonego świadczenia nadającego się do realizacji w drodze egzekucji. Wynika to bezpośrednio z art. 197 ust. 1 p.z.p., wykluczającego stosowanie w stosunku do nich regulacji art. $1212 \S 1$ k.p.c.,

${ }^{38}$ Zob. K. Piasecki, System prawa procesowego cywilnego, t. 2: Postepowanie rozpoznawcze przed sądami pierwszej instancji, pod red. Z. Resicha, Wrocław 1987, s. 216.

${ }^{39}$ P. Pogonowski, Realizacja prawa do sądu w postępowaniu cywilnym, Warszawa 2005, s. 105; J.P. Tarno, Prawo o postępowaniu przed sądami administracyjnymi. Komentarz, Warszawa 2004, s. 288.

${ }^{40}$ Zob. T. Woś, Prawo o postępowaniu przed sądami administracyjnymi. Komentarz, Warszawa 2009, s. 536. 
przewidujących możliwość uznania przez sąd wyroku sądu polubownego, w wyniku czego uzyskuje on moc równą wyrokowi sądu powszechnego.

Uzyskanie przez nie mocy równej orzeczeniom sądowym jest ponadto uzależnione od woli strony postępowania. Zgodnie bowiem $z$ art. 197 ust. 2 p.z.p. o stwierdzeniu wykonalności orzeczenia KIO sąd orzeka na jej wniosek. Powyższe ukazuje, że orzeczenia KIO, wobec których nie została stwierdzona wykonalność zarówno ze względu na to, że nie nadają się do wykonania, jak i ze względu na brak podjęcia stosownej aktywności przez stronę postępowania odwoławczego, nie uzyskują mocy prawnej równej orzeczeniom sądowym. Niezależnie od stwierdzenia albo niestwierdzenia wykonalności aktu żaden wyrok KIO nie jest orzeczeniem judykatywy.

\subsection{Wyroki KIO a wyroki sądów polubownych}

Biorąc pod uwagę treść art. 185 ust. 7 p.z.p. nakazującego w zakresie nieuregulowanym stosować przepisy k.p.c. o sądzie polubownym, należy zastanowić się nad możliwością zaklasyfikowania aktów wydawanych przez KIO do kategorii orzeczeń sądów arbitrażowych.

W celu zachowania precyzji wypowiedzi niezbędne jest wskazanie, że KIO nie może zostać uznane za sąd polubowny, a postępowanie przed nim za arbitraż. Argumentując tę tezę, należy wskazać na konstytutywne różnice pomiędzy postępowaniem przed KIO a sądem arbitrażowym. Kompetencja do rozpoznawania spraw przez sądy arbitrażowe wynika z umowy stron (zapis na sąd polubowny), natomiast w przypadku sporów wynikłych na etapie postępowania o udzielenie zamówienia strony działają na podstawie przepisu prawa, który określa, w jaki sposób, do jakiego organu i w jakim terminie musi zostać złożone odwołanie. Zarówno strony postępowania o udzielenie zamówienia publicznego, jak i zamawiający jednostronnie nie mogą w drodze zapisów przekazać rozpoznawania sporów powstałych na etapie udzielenia zamówienia do rozpoznania innemu organowi niż KIO.

Sposób prowadzenia postępowania przed sądem polubownym (art. 1184 k.p.c.) jest wynikiem autonomicznej woli stron, zaś w postępowaniu przed KIO sposób procedowania regulują wyłącznie akty normatywne. Ponadto strony postępowania polubownego mają wpływ na wybór arbitrów (art. 1171 k.p.c.), odmiennie, niż ma to miejsce w postępowaniu odwoławczym, w którym skład orzekający jest wyznaczany 
przez prezesa KIO według kolejności wpływu odwołań z alfabetycznej listy członków Izby (art. 188 ust. 2 p.z.p.).

Selektywnie wskazane różnice jednoznacznie przesądzaja, że KIO nie jest sądem arbitrażowym, a postępowanie odwoławcze ma odmienny charakter prawny niż postępowanie przed sądem polubownym.

Poczynione rozważania mają kluczowe znaczenie ze względu na występujące w dogmatyce prawa arbitrażowego koncepcje charakteru prawnego orzeczeń wydawanych przez sądy polubowne. Jak wskazuje Ł. Błaszczak, powołując się na literaturę zagraniczną oraz krajowa, w tej kwestii wyróżnia się trzy teorie: kontraktowa, jurysdykcyjną oraz mieszaną ${ }^{41}$. Pierwsza $z$ wymienionych podkreśla przede wszystkim umowną naturę arbitrażu, z której wyprowadza wniosek o umownym charakterze orzeczenia sądu polubownego. Precyzując, orzeczenie tego podmiotu jest umową pełnomocnictwa, stanowiącą konsekwencję wcześniej zawartej umowy, w której znajduje się zapis na sąd polubowny. Zgodnie $\mathrm{z}$ tą koncepcją orzeczenie arbitrażowe stanowi prywatny akt kształtujący, nieprzypominający w swojej konstrukcji orzeczenia sądu państwowego. Wyroki tego rodzaju są wprawdzie akceptowane przez aparat państwowy, nie są jednak powiązane ze środkami przymusu państwowego. Przyjęcie przywołanej koncepcji uniemożliwia przyrównanie charakteru prawnego orzeczeń KIO do orzeczeń sądów arbitrażowych z powodu przytoczonych różnic proceduralnych, przede wszystkim zaś $\mathrm{z}$ powodu nieistnienia stosownego zapisu umownego.

Kierując się przyjętymi celami badawczymi, należy odwołać się do teorii procesowej, stanowiącej przeciwieństwo teorii kontraktowej, koncentrującej się na kompetencji państwa do regulowania postępowania arbitrażowego. $W$ ujęciu tej teorii konieczne jest oddzielenie umownego charakteru zapisu na sąd polubowny od charakteru wydawanych przez niego orzeczeń. Sam zapis jest podstawą do aktualizacji kompetencji orzeczniczej arbitrów, jednakże kompetencja orzecznicza została przyznana im przez ustawodawcę i wynika bezpośrednio $z$ aktu normatywnego. Wyrok arbitrażowy traktowany jest jako akt rozstrzygający spór, wydany przez podmiot prywatny z upoważnienia władzy państwowej (prywatyzacja zadań publicznych). W ten sposób akcentowane jest podobieństwo wyroków sądów arbitrażowych do orzeczeń sądów powszechnych, z tą jednak różnica, że, podobnie jak orzeczenia

${ }^{41}$ Zob. Ł. Błaszczak, Wyrok sadu polubownego w postępowaniu cywilnym, Warszawa 2010, s. 81-103. 
$\mathrm{KIO}$, nie mają one charakteru solennego. Odmiennie jednak niż wyroki KIO orzeczenia arbitrażowe nie mają waloru publicznoprawnego, gdyż wydawane są przez podmioty prywatne.

Koncepcja mieszana przyjmuje, że wyrok sądu polubownego jest czymś pośrednim między umową a wyrokiem sądu państwowego. Ujęcie to jest najbardziej zróżnicowane, co wynika z przyjęcia różnego natężenia argumentów przemawiających za wyrokiem jako umową bądź wyrokiem jako aktem orzeczniczym zbliżonym do wyroku sądu państwowego. Zgodnie z koncepcją mieszaną orzeczenie sądu arbitrażowego uznawane jest za prywatnoprawny akt orzeczniczy, niebędący oficjalną decyzją państwa, któremu państwo nadaje skutki publicznoprawne.

Dwie ostatnie koncepcje, w pewnym zakresie, mogą być pomocne w określeniu charakteru prawnego nadanego wyrokom KIO przez ustawodawcę. Pomijając wiele różnic organizacyjno-ustrojowych dzielących sądy arbitrażowe i organ administracji publicznej, jakim jest KIO, a także różnic proceduralnych, można zauważyć, że akty te mają pewne cechy wspólne.

Najistotniejsza, w kontekście celu podjętych badań, jest okoliczność, że wyrok sądu polubownego z chwilą wydania go nie uzyskuje mocy prawnej równej wyrokowi sądu państwowego. Zgodnie z art. 1212 k.p.c. wyroki sądu polubownego mają moc prawną równą z wyrokiem sądu po ich uznaniu przez sąd albo po stwierdzeniu przez sąd ich wykonalności ${ }^{42}$. Wyroki nienadające się do wykonania w drodze egzekucji podlegają uznaniu; wyroki nadające się do wykonania w drodze egzekucji podlegają stwierdzeniu ich wykonalności (art. 1214 k.p.c.).

A contrario wyroki, które nie zostały uznane przez sąd państwowy lub wobec których organ ten nie stwierdził wykonalności, nie mają mocy wyroku sądu powszechnego. Będą to zatem swoiste akty nazwane: wyroki sądu polubownego, niewywołujące skutków prawnych takich jak wyroki sądu państwowego.

\subsection{Wyroki KIO a indywidualne akty administracji publicznej}

Indywidualny akt administracyjny jest jedną z prawnych form działania administracji. Częstokroć jest uznawany za najbardziej typową i podstawową

${ }^{42}$ Zgodnie $\mathrm{z}$ art. $1213 \S 1$ k.p.c. uznanie albo stwierdzenie wykonalności wyroku sądu polubownego lub ugody przed tym sądem zawartej sąd orzeka na wniosek strony. W ramach postępowania o uznanie lub stwierdzenie wykonalności wyroku sądu polubownego dokonywana jest kontrola tychże aktów. 
formę ${ }^{43}$, tak jak wyrok jest formą charakterystyczną dla sądu ${ }^{44}$. Pomimo to, jak słusznie zauważa J. Łętowski, pojęcie indywidualnego aktu administracyjnego, wbrew pozorom, nie jest ani jasne, ani bezsporne ${ }^{45}$. W świetle takiej konstatacji niezbędne jest przedstawienie definicji skonstruowanych przez przedstawicieli doktryny prawa administracyjnego ${ }^{46}$.

J. Borkowski zdefiniował akt administracyjny jako władczą i jednostronną formę działania administracji, podlegającą wykonaniu z możliwością użycia przymusu państwowego ${ }^{47}$. Z kolei Z. Leoński wskazał, że jest to objaw woli organu administracji publicznej o charakterze władczym, który kształtuje prawa i obowiązki jednostki w konkretnej sytuacji ${ }^{48}$. K. Ziemski w sposób szczegółowy definiuje pojęcie indywidualnego aktu administracyjnego, wskazując, że jest on aktem wydawanym w sferze zewnętrznej działania administracji w celu wywołania bezpośredniego skutku prawnego w sferze prawa publicznego, z którym nierozerwalnie związane jest pojęcie władczości, składające się $\mathrm{z}$ trzech elementów: jednostronności działania podmiotu administrującego, domniemania jego prawidłowości oraz dopuszczalności stosowania przymusu ${ }^{49}$.

Zważając na poczynione ustalenia dotyczące statusu prawnego KIO oraz treść art. 104 k.p.a., należy się zastanowić, czy wyrok KIO nie może zostać uznany za decyzję administracyjną, stanowiącą formę podstawową rozstrzygania spraw, co do jej istoty, przez organy administracji publicznej. W przypadku innych kolegialnych organów administracji publicznej forma ta została zachowana ${ }^{50}$.

Zaklasyfikowaniu wyroku KIO do kategorii decyzji administracyjnych z całą pewnością nie przeciwstawia się użyta przez ustawodawcę nomenklatura. Użycie nazwy "wyrok" nie może przesądzać jednoznacznie o tym, że dane rozstrzygnięcie nie jest decyzją administracyjną. Innymi słowy, posługiwanie się przez ustawodawcę konkretną nazwą nie

${ }^{43}$ E. Ura, E. Ura, Prawo administracyjne, Warszawa 1999, s. 79-81.

${ }^{44}$ Z. Niewiadomski, Prawo administracyjne. Część ogólna, Warszawa 2011, s. 130.

${ }^{45} \mathrm{~J}$. Łętowski, Prawo administracyjne. Zagadnienia podstawowe, Warszawa 1990, s. 183.

${ }^{46}$ Gruntowną analizę pojęcia indywidualnego aktu administracyjnego w doktrynie i przepisach prawnych przeprowadza K. Ziemski w pracy Indywidualny akt administracyjny jako forma prawna działania administracji, Poznań 2005, s. 157-516.

47 J. Borkowski, Decyzja administracyjna, Łódź-Zielona Góra 1998, s. 22.

${ }^{48}$ Z. Leoński, Zarys prawa administracyjnego, Warszawa 2004, s. 282.

${ }^{49}$ K. Ziemski, op. cit., s. 524.

${ }^{50}$ Zob. J.P. Tarno, Samorzadowe Kolegia Odwoławcze jako szczególne organy administracji publicznej, „Samorząd Terytorialny” 1997, nr 1-2, s. 15. 
musi przesądzać o pozadecyzyjnym charakterze rozstrzygnięcia. Czynnikiem klasyfikującym jest treść aktu, a nie jego nazwa ${ }^{51}$. W przepisach materialnego prawa administracyjnego występuje wiele różnych nazw, np. orzeczenie, pozwolenie, nakaz, nominacja. Na powyższe zwrócił uwagę również Sąd Najwyższy, stwierdzając, że "nazwanie przez ustawodawcę danego aktu «powołaniem» na stanowisko nie oznacza, iż nie jest on decyzją administracyjna, bo nie różni się od nominacji innych funkcjonariuszy, a nie ma cech powołania jako aktu nawiązania stosunku pracy na podstawie przepisów $\mathrm{KP}^{\prime \prime 52}$.

Decyzją administracyjną jest zatem indywidualny akt, który został przez ustawodawcę za taki uznany. Ponadto są nimi również inne akty wykazujące cechy konstytutywne decyzji administracyjnej. W literaturze powszechnie uznaje się, że decyzja administracyjna jest aktem administracyjnym sensu stricto, wydawanym w sferze zewnętrznej działania administracji w celu wywołania bezpośredniego skutku prawnego w sferze prawa publicznego, charakteryzującym się władczością, indywidualnością i konkretnością ${ }^{53}$. Nieodzowne jest zatem poddanie analizie wyroków KIO z uwzględnieniem cech charakterystycznych dla decyzji administracyjnej.

Jednym z kwalifikatorów decyzji administracyjnych jest cel ich wydania, za który uznaje się wywołanie bezpośrednich skutków prawnych w sferze prawa publicznego. Biorąc pod uwagę trudności w repartycji sfery publicznej od sfery prywatnej w przypadku podejmowania działań przez podmioty publiczne, przesłanka ta może rodzić wiele problemów. Nie powinno budzić wątpliwości, że celem wyrokowania przez KIO jest zachowanie stanu zgodności działań zamawiającego z prawem. Powyższe zostało ukazane w ramach rozważań poczynionych w niniejszym artykule. Zachowanie stanu praworządności działań zamawiającego wykazuje silną korelację z dbałością o ochronę interesu publicznego, co stanowi wyróżnik sfery publicznej. Tezę tę wzmacnia rodzaj rozstrzygnięć mogących zostać orzeczonymi w wyroku KIO.

Kolejnym wyróżnikiem decyzji jest sfera, w jakiej akty te są wydawane. Niewątpliwie wyroki KIO są aktami kierowanymi do podmiotów niezależnych od tego organu. Zamawiający będący adresatami powinności

${ }^{51}$ Wyrok Naczelnego Sądu Administracyjnego (NSA) z 22 IX 1981 r., sygn. Sa 791/81, LEX nr 9638; postanowienie NSA z 20 XI 1981 r., sygn. II SA 848/81, LEX nr 9652.

52 Postanowienie SN z 8 V 1992 r., sygn. III ARN 29/92, OSNCP 1993, nr 3, poz. 44.

${ }^{53}$ Zob. B. Adamiak, Wadliwość decyzji administracyjnej, Wrocław 1986, s. 22-23; J. Zimmermann, Prawo administracyjne, Zakamycze 2003, s. 343; idem, Decyzje administracyjne, „Wspólnota” 2000, nr 46, s. 43. 
wyrażonych w wyroku są podmiotami działającymi na podstawie zasady decentralizacji podejmowanych czynności zarówno na etapie przygotowywania, jak i przeprowadzania postępowań o udzielenie zamówienia publicznego. Brak podległości, będącej cechą konstytutywną relacji, w której wydawane są akty o charakterze wewnętrznym, bezpośrednio wskazuje na pozostawanie ich w sferze zewnętrznej.

Akty te kierowane są do podmiotów niepozostających w stosunku podległości w celu uregulowania ich indywidualnej oraz konkretnej sytuacji. Ad exemplum, w rozstrzygnięciu zawartym w wyroku $\mathrm{KIO}$ z 31 marca 2016 r. ${ }^{54}$ Izba, uwzględniając odwołanie, nakazała zamawiającemu Skarbowi Państwa, Teatrowi Narodowemu w Warszawie (indywidualne oznaczenie adresata aktu będącego podmiotem zewnętrznym):

1. unieważnienie czynności unieważnienia postępowania,

2. unieważnienie czynności odrzucenia oferty wykonawcy A. Spółka z ograniczoną odpowiedzialnością w W.,

3. dokonanie ponownej oceny ofert (skonkretyzowany nakaz działania w konkretnej sytuacji).

Ostatnią cechą decyzji administracyjnych, pod kątem której należy dokonać analizy wyroków KIO, jest władczość. Zasadniczo orzeczenia KIO nakazują podjęcie określonych działań przez zamawiającego (wykonania, powtórzenia lub unieważnienia zakwestionowanej czynności). Przy czym zgodnie z art. 192 ust. 6 p.z.p. KIO nie może nakazać zawarcia umowy ${ }^{55}$. Nakazanie zamawiającemu wykonania czynności następuje wtedy, gdy zamawiający nie dokonał czynności obowiązkowej zgodnie z przepisami p.z.p. (np. nie wezwał wykonawców do uzupełnienia przedłożonych ofert o dokumenty potwierdzające spełnienie warunków udziału w postępowaniu zgodnie $z$ art. 26 ust. 3 p.z.p.). Orzeczenie nakazujące powtórzenie czynności wydawane jest, gdy dana czynność została dokonana z naruszeniem przepisów ustawowych regulujących sposób jej dokonania (np. ocena ofert). Unieważnienie czynności zamawiającego następuje $\mathrm{w}$ wypadku wadliwego dokonania przez zamawiającego czynności bądź w wypadku dokonania przez zamawiającego czynności mającej wpływ na wynik postępowania, a nieprzewidzianej przez prawo.

W żadnym z wyżej wskazanych przypadków wyrok KIO nie zastępuje działań zamawiającego, np. decyzji o unieważnieniu postępowania, ale jedynie nakazuje ich podjęcie. Jak wskazuje A. Sołtysińska, „przyjęty

\footnotetext{
${ }^{54}$ Wyrok KIO z 31 III 2016 r., sygn. KIO 396/16, LEX nr 2015728.

${ }^{55}$ Wyrok KIO z 28 VII 2011 r., sygn. KIO 1372/11, LEX nr 863599.
} 
przez polskiego ustawodawcę środek ochrony prawnej nie gwarantuje prawa do uchylenia bezprawnej decyzji zamawiającego przez Izbę, a jedynie ma na celu doprowadzenie do uchylenia tej decyzji przez samego zamawiającego" ${ }^{\prime \prime 6}$. W tym zakresie wyroki KIO są zbliżone do decyzji kasacyjnych, uchylających i przekazujących sprawę do ponownego rozpatrzenia, wydawanych przez organ odwoławczy (art. $138 \S 2$ k.p.a.). Również w nich organ administracyjny wyłącznie nakazuje dokonanie określonych czynności, jednocześnie mogąc nakazać uwzględnienie przy ponownym rozpatrzeniu sprawy poszczególnych okoliczności.

Indywidualny akt stosowania prawa wydawany przez KIO jest zatem jednostronnym oświadczeniem woli organu. Władczość należy łączyć jednak nie tylko z jednostronnym określeniem obowiązków zamawiającego, ale również z możliwością zastosowania środków przymusu w przypadku niezastosowania się do woli KIO wyrażonej w wyroku. Regulacje p.z.p. nie przewidują żadnego instrumentu prawnego, jaki Izba mogłaby zastosować w takim przypadku. Przepisy p.z.p. nie uprawniają również pomiotów zewnętrznych do zainicjowania działań przez $\mathrm{KIO}^{57}$. Stronie przysługuje jedynie uprawnienie do wszczęcia nowego postępowania egzekucyjnego, zmierzającego do przymuszenia zamawiającego do wykonania wyroku KIO. Uprzednio strona musi podjąć czynności zmierzające do uzyskania przez akt wydany przez KIO mocy prawnej równej z wyrokiem sądu powszechnego, a zatem uzyskać klauzulę wykonalności (art. 197 ust. 1 p.z.p.). W związku z treścią rozstrzygnięć zawartych w wyroku KIO w znacznej mierze będą one podlegały egzekucji na podstawie przepisów dotyczących egzekucji świadczeń o charakterze niepieniężnym i niezastępowalnym (art. 1050 § 1 k.p.c.).

Należy uwzględnić również drugą kategorię rozstrzygnięć, jakie moga zostać zawarte w wyroku wydanym przez KIO, w sytuacji gdy organ ten orzekał po zawarciu umowy w sprawie zamówienia publicznego i zachodzą przesłanki wskazane w art. 146 ust. 1 p.z.p. W wyrokach wydawanych po zawarciu umowy dostrzec można przejawy przymusu, władczości, którymi są sankcje o charakterze cywilnoprawnym (nieważność umowy $)^{58}$ oraz administracyjnoprawnym (kary finansowe) ${ }^{59}$. Mają

\footnotetext{
${ }^{56}$ A. Sołtysińska, Glosa do wyroku TS z dnia 2 czerwca 2005 r., C-15/04, LEX nr 96473.

${ }^{57}$ Wyrok KIO z 23 VII 2013 r., sygn. KIO 1654/13, LEX nr 1396332.

${ }^{58}$ Konsekwencją uprawomocnienia się wyroku KIO unieważniającego umowę jest nieważność umowy od momentu jej zawarcia (art. 146 ust. 3 p.z.p.).

${ }^{59}$ Kary finansowe zamawiający zobowiązany jest uiścić w terminie 30 dni od dnia uprawomocnienia się orzeczenia KIO na rachunek bankowy UZP (art. 195 ust. 1 p.z.p.). Nieuiszczone kary podlegają egzekucji w trybie ustawy o egzekucji w administracji.
} 
one charakter wyłącznie represyjny oraz prewencyjny. Nie zmierzają do zapewnienia realizacji obowiązków prawnych, lecz jedynie stanowią dolegliwość wymierzaną zamawiającemu za działanie sprzeczne $\mathrm{z}$ zasadą legalizmu, a ponadto mają stanowić dodatkowy bodziec motywujący do przestrzegania regulacji normatywnych. Nie są one zatem elementem władczego przymuszenia do realizacji woli organu wyrażonej w akcie administracyjnym. Rekapitulując poczynione rozważania, wyroki wydawane przez KIO de lege lata, pomimo posiadania cech wspólnych z indywidualnymi aktami administracyjnymi, w tym decyzjami administracyjnymi, nie mogą zostać uznane za przejaw działania administracji publicznej w tejże formie.

\section{Podsumowanie}

Precyzyjne określenie charakteru prawnego wyroków KIO napotyka na liczne problemy. Można je sprowadzić do dwóch kategorii: generalnej oraz konkretnej. Pierwszą zawrzeć można w stwierdzeniu, że precyzyjna repartycja pomiędzy wyrokiem sądowym, wyrokiem sądu polubownego a indywidualnym aktem administracyjnym, abstrahująca od cech podmiotowych, jest utrudniona ze względu na przynależność wymienionych aktów do kategorii stosowania prawa w indywidualnej oraz konkretnej sytuacji ${ }^{60}$. Zasadniczo rozróżnienie tychże aktów prawnych dokonywane jest na podstawie statusu organizacyjno-prawnego organu stosującego prawo oraz charakteru postępowania zmierzającego do ich wydania. Te dwa mierniki mogą okazać się zawodne w przypadku wprowadzenia przez ustawodawcę rozwiązań atypowych.

Takie nietypowe sytuacje skutkują powstaniem problemów o charakterze konkretnym. Nie są one charakterystyczne wyłącznie dla omówionych regulacji p.z.p. Podobne wątpliwości pojawiają się również w odniesieniu do innych aktów, m.in. „orzeczeń" SKO wydawanych w kwestii wysokości opłaty rocznej (art. 79 ustawy o gospodarce nieruchomościami $\left.{ }^{61}\right)$.

${ }^{60}$ B. Adamiak, op. cit., s. 13.

${ }^{61}$ Ustawa z dnia 21 VIII 1997 r. o gospodarce nieruchomościami (tekst jedn. Dz.U. 2015, poz. 1774). Zob. J.P. Tarno, A. Wrzesińska-Nowacka, Postępowanie w sprawach opłaty za użytkowanie wieczyste, "Samorząd Terytorialny" 1995, nr 7-8, s. 109-117; R. Sawuła, Postępowanie w sprawach opłaty za użytkowanie wieczyste. Kilka uwag na tle artykułu J.P. Tarno i A. Wrzesińskiej-Nowackiej, "Samorząd Terytorialny” 1996, nr 3, s. 34-39; K. Podgórski, Nowa forma aktualizacji, „Wspólnota” 1995, nr 6, s. 19; G. Bieniek, Samorządowe kolegia 
Poczyniona analiza pozwala przyjąć, że wyroki KIO stanowią sui generis prawną formę działania administracji w sprawach indywidualnych. Nie są one decyzjami administracyjnymi, gdyż nie przejawiają elementu władczości. W pewnym zakresie są zbliżone do wyroków sądów polubownych, m.in. co do możliwości uzyskania przez nie mocy prawnej równej z wyrokiem sądu powszechnego ${ }^{62}$. Wykazywanie pewnych cech wspólnych z wyrokami arbitrażowymi nie powinno jednak skutkować zaliczeniem ich do tejże kategorii, m.in. ze względu na niewątpliwie publicznoprawny status KIO. Jednocześnie należy podkreślić, że uzyskiwanie w pewnych sytuacjach przez te akty mocy prawnej równej z wyrokami sądów powszechnych nie stanowi przesłanki pozwalającej zaklasyfikować je do kategorii orzeczeń wydawanych przez organy sądownicze.

Motywów wprowadzenia przez ustawodawcę swoistej formy działania KIO można upatrywać w sposobie ukształtowania postępowania odwoławczego w regulacjach ustawy o zamówieniach publicznych ${ }^{63}$. W art. 88-92 u.z.p. wyróżnione zostały następujące etapy tego postępowania: złożenie odwołania, wyznaczenie arbitrów przez uczestników postępowania (jeżeli strona nie wyznaczyła arbitra, uprawnienie to przechodziło na prezesa UZP), powołanie zespołu arbitrów (zespół składał się z trzech arbitrów wybranych $\mathrm{z}$ listy prowadzonej przez prezesa UZP, jeden wybierany był przez wykonawcę, jeden przez zamawiającego i jeden przez prezesa UZP, przy czym superarbitrem był ten wybrany przez prezesa UZP), rozpatrzenie odwołania przez zespół arbitrów, wydanie orzeczenia. Procedura ta stanowiła odwzorowanie procedury przed sądem arbitrażowym. Zarówno sposób ukształtowania postępowania odwoławczego, w tym konieczność stosowania przepisów k.p.c. o sądzie polubownym, jak i charakter prawny aktów wydawanych przez KIO stanowi szkodliwą reminiscencję rozwiązań przewidzianych w u.z.p. Negatywna ocena przyjętego rozwiązania nie wynika wyłącznie z trudności klasyfikacyjnych. Ukształtowanie przez ustawodawcę swoistej prawnej formy działania nie tylko nie przynosi żadnej wartości dodanej, ale również powoduje liczne problemy praktyczne, m.in. dotyczące skutków prawnych orzeczeń wydawanych przez

odwoławcze a gospodarka nieruchomościami po reformie administracji publicznej, "Casus" 1999, nr 11, s. 10-15.

${ }^{62}$ Uchwała SN z 6 XI 2002 r., sygn. III CZP 68/02, OSNC 2003, nr 7-8, poz. 103.

${ }^{63}$ Ustawa z dnia 10 VI 1994 r. o zamówieniach publicznych (Dz.U. Nr 76, poz. 344 ze zm.), dalej „u.z.p.”. 
KIO w zakresie ewentualnego związania nimi innych organów oraz sądów, co ma istotne znaczenie w postępowaniach cywilnych, m.in. o odszkodowanie albo o zwrot wadium ${ }^{64}$.

Przywołane problemy występują również w przypadku wyroków sądów polubownych. Odmienna sytuacja ma miejsce w odniesieniu do decyzji administracyjnych. Należy zatem w pełni podzielić pogląd wyrażony przez J. Niczyporuka, że KIO powinna wydawać rozstrzygnięcia wyłącznie w formie decyzji i postanowien' ${ }^{65}$.

\section{THE LEGAL NATURE OF JUDGMENTS DELIVERED BY THE NATIONAL APPEALS CHAMBER}

\section{Su m mary}

The regulation of the legal nature of an appeal proceeding or a judgment crowning the proceeding is ambiguous and unclear. The National Appeals Chamber which issues a judgment decides upon the validity of a contract, the obligations of the contracting authority, financial penalties, and, indirectly, the actions taken by contractors. The influence of such decisions is of theoretical and practical significance and justifies an analysis presented in the paper. Thus the constitutive features of judgments handed down by a public administration body have been analysed and compared with typical forms of law enforcement (judicial decisions of the common courts, decisions issued by arbitration courts and individual administrative decisions). The latter have been given particular attention. The deliberations were based on the position of the doctrine of the law on public procurements, provisions of civil law and administrative law, as well as judicial decisions and judgments issued by the National Appeals Chamber. These were then analysed in the light of normative regulations of the Act on Public Procurements. The analysis revealed a multitude of problems resulting from the adoption by the legislature of atypical forms of action by the National Board of Appeal. The analysis provides the basis for further research aimed to create a coherent system regulating public procurements to ensure its proper functioning and to reduce the possibility of further interpretative problems.

Keywords: public procurement law - judgments of the National Appeals Chamber - an appeal

${ }^{64}$ Zob. Ł. Błaszczak, Moc wiążąca wyroków Krajowej Izby Odwoławczej w postępowaniach sądowych związanych ze zwrotem wadium, „Iustitia. Kwartalnik Stowarzyszenia Sędziów Polskich" 2013, nr 1(11), s. 17-18.

${ }^{65}$ J. Niczyporuk, Skuteczność postępowania odwoławczego..., s. 42. 